\title{
Mersin ilinde yetiştirilen muz meyvelerinde hasat sonrasında görülen fungal hastalık etmenlerinin belirlenmesi
}

Determination of postharvest fungal disease agents on banana fruits growing in Mersin province

\section{Seyfeddin FARUK ${ }^{1 / D}$ (i), Soner SOYLU ${ }^{2}$ iD}

${ }^{1}$ Republic of Turkey Ministry of Agricultureand Forestry, Alata Horticultural Research Institute, Erdemli-Mersin, Turkey. ${ }^{2}$ Hatay Mustafa Kemal University, Faculty of Agriculture, Department of Plant Protection, Antakya-Hatay, Turkey.

\section{MAKALE BILGISI / ARTICLE INFO}

\section{Makale tarihçesi / Article history:}

DOI: $10.37908 /$ mkutbd.936083

Geliş tarihi /Received:11.05.2021

Kabul tarihi/Accepted:07.06.2021

\section{Keywords:}

Banana, post-harvest, fungal disease agents, fruit rot.

\footnotetext{
Corresponding author: Seyfeddin FARUK $\bowtie:$ seyfeddin49@hotmail.com
}

\section{Ö ZET / A B STR A C T}

Atıf / Citation: Faruk S, Soylu S (2021) Mersin ilinde yetiştirilen muz meyvelerinde hasat sonrasında görülen fungal hastalık etmenlerinin belirlenmesi. MKU. Tar. Bil. Derg. 26(2) : 399-411. DOI: 10.37908/mkutbd.936083

\begin{abstract}
Aims: This study was carried out for the isolation and identification of common postharvest fungal disease agents on banana fruits sampled from packaging houses in districts of Mersin province such as Bozyazı, Anamur and Erdemli, during 2013-2014 growing season.

Methods and Results: During disease survey in 2013 and 2014 bananagrowing seasons, diseased/suspected banana fruit samples were taken from warehouses and packing houses in different districts of Mersin province. Postharvest fungal disease agents were isolated from the banana fruits and identified according to their morphological structures. Following isolation, a total of 238 fungal isolates were obtained from 197 different diseased fruits. Isolates belonging to Fusarium spp. (21.8\%) were the most prevalent fungal isolate determined on fruits showing crown rot disease symptoms followed by Fusarium verticillioides $(13.4 \%), F$. oxysporum (10.5\%), F. proliferatum (9.7\%) and Thielaviopsis paradoxa (2.5\%), respectively. Isolates belong to Fusarium spp. (7.6\%), Musicillium theobromae $(2.9 \%)$ and Deightoniella torulosa $(1.7 \%)$ were isolated and determined as causal disease agents responsible for fruit end rot disease symptoms. F. verticillioides $(4.2 \%)$ was determined as the causal disease agent of internal rot symptoms of the fruits. Alternaria alternate $(10.9 \%)$, Penicillium spp. (8.8\%), Aspergillus niger (4.6\%) and Cladosporium cladosporioides (1.3\%) isolates were identified as secondary (opportunistic) disease agents on banana fruit showing different rotting symptoms.

Conclusions: In Turkey, there has not been any research on the fungal agent(s) that cause a significant postharvest loss in banana fruits up to now. With this study, fungal disease agents that occur after harvesting and cause quality and quantity losses in banana fruits grown in Mersin province were determined. Results of this study fulfilled partially deficiency in this area.

Significance and Impact of the Study: The results obtained in this study are of the nature to shed light on future studies on post-harvest diseases and their control, which should be studied primarily in banana fruits.
\end{abstract}




\section{Giriş}

Tropik iklim meyvesi olan muz, birçok ülkede mikroklimalarda subtropik iklim koşullarında da yetiştirilebilmektedir. Dünyada kültürü yapılan muz, Scitamineae takımı, Musaceae familyası, Musa cinsine dâhildir. Bu cinste çok sayıda partenokarp meyve veren klonlar mevcuttur. Sofralık muzlar ilk iki gruba girerler. $M$. acuminata türleri genelde çekirdeksiz yenen türlerdir. Güney Asya ülkeleri ile Doğu Hindistan bölgesinde yetişen $M$. balbisiana ise çekirdekli meyvelere sahip tür olup, daha çok hastalık ve zararlılara karşı dayanıklı çeşitlere sahiptir. Geri kalan muz gruplarının büyük bir kısmı yenmeden önce sebze gibi pişirilen "Plantain (nişastalı)" muzlardır. Dünyada yetiştiriciliği yapılan muzların \%41'ini "Cavendish", \%14'ünü "Gros Michel", \%21'ini "Plantain" grupları ve \%24'ünü ise pişirilerek yenen muz grupları oluşturmaktadır. Ülkemizde yapılan muz yetiştiriciliğinde son 10 yıla kadar bahçe tesisinde sadece bodur Cavendish (Dwarf Cavendish) muz klonu kullanılmakta iken, günümüzde bunun yanı sıra "Grand Nain" klonu da yetiştirilmektedir (Anonim, 2010).

Muz yüksek verimliliği ve bütün yıl boyunca ürün vermesi nedeniyle subtropik bölgede meyve tarımı içinde önem kazanmıştır (Gangwar ve ark.,2008). Dünyada 120'den fazla ülkede yetiştiriciliği yapılan meyve olarak veya yemeklik olarak tüketilen muz, pirinç, buğday ve mısır'dan sonra dünyada en fazla üretimi yapılan 4 . üründür (Arias ve ark., 2003). Dünya meyve üretimine bakıldığında ise portakal'dan sonra, üzümden önce olmak üzere ikinci sırada yer alır. Ekvatorun 30. Güney ve 30. Kuzey enlem dereceleri arasında yer alan ülkelerden Hindistan, Çin, Endonezya, Brezilya ve Ekvator dünyanın önde gelen ilk 5 muz üreticisi ülkeler arasında yer almaktadır (Anonymous, 2019). Türkiye'de muz yetiştiriciliğinin ana üretim alanları Akdeniz Bölgesinde, 36. ve 37. enlem dereceleri arasında kalan MersinAntalya kıyı şeridinde, özellikle de Toros Dağları tarafından çevrelenmiş olan, mikro-klima olanaklarının daha uygun bulunduğu Mersin iline dahil olan Anamur ve Bozyazı ilçeleri ile, Antalya ilinin Alanya ve Gazipaşa ilçeleridir. Son yıllarda yetiştirme tekniklerinin gelişmesi, ürün arz talep miktarının artması ve üretim teşvikleri sonucunda Adana ve Hatay illerinin Çukurova, İskenderun ve Arsuz gibi sahil ilçelerinde gerek örtüaltı gerekse açık alanlarda ekonomik olarak yetiştirilmektedir.

Ülkemizdeki muz üretimi, iç tüketimin yaklaşık yarısını karşılamaktadır. Tüketim ile üretim arasındaki fark ithalat yoluyla karşılanmakta olup uluslararası beş firma dünya muz ticaretinin \% 80'ini kontrol etmektedir.
Türkiye'nin 2015 yılı muz tüketimi 477.318 ton iken, üretim miktarı 270.500 ton olmuştur (Anonim, 2020). Ülkemizde muz üretiminin yakın tarihine bakıldığında, 1994 'te 12.000 dekar alanda 30.000 ton ürün elde edilirken, bu oran 2000 yılında 20.000 dekar alan ve 80.000 tona ulaşmıştır. Ülkemizde 2015 yılında toplam 58380 da alanda 270.500 ton olan muz üretimi, 2019 yılında 84880 da alanda 728.133 tona ulaşmıştır (Anonymous, 2019). Ülkemizde 2020 yılı itibarıla yetiştirilen muzun 421.406 tonu Adana ve Mersin illerine bağı ilçelerde, 296.456 tonu Antalya iline bağlı ilçelerde, 5668 tonu ise Hatay ilinde yer alan ilçelerinde yapılmıştır (Anonim, 2020). Son yıllarda söz konusu alanlarda hızlı bir şekilde örtüaltı yetiştiriciliğine geçiş yapılmış olup üretim ve kalitede önemli derecede artış sağlanmıştır. Muz yetiştiriciliği yapılan yörelerde yaşayan insanların \%45'inin geçim kaynağını muz üretimi oluşturmaktadır (Pınar ve ark., 2011).

Muz meyvesinin uluslararası taşımacılık tarihçesine baktığımızda, 1960 yıllarına kadar muz bitkisinin daha çok "Gros-Michel" isimli alt tür çeşitlerinin yetiştiriciliğinin yapıldığı, Gros-Michel muz çeşidinin fungal Panama hastalık etmeni Fusarium oxysporum f. sp. cubense ye karşı oldukça duyarlı olması nedeni ile dünyanın önde gelen muz üreticisi ülkeleri bu çeşidi yetiştirmeyi bırakarak şu an tükettiğimiz "Cavendish" grubu muz çeşitlerine dönüş yapmışlardır. Klimakterik bir meyve olan muz çok kısa depolama ömrüne sahip olup, derim sonrası birçok hastalık etmenine karşı duyarlıdır ve yüksek oranda kayıplar meydana gelmektedir (Basel ve ark., 2002). Muz meyveleri diğer olgun meyve ve sebzeler gibi yüksek neme ve zengin besin maddelerine sahip olması nedeni ile mikroorganizmaların saldırısına karşı hassas özelliğe sahiptir (Snowdon, 2010). Açık alan veya seralarda yapılan muz yetiştiriciliğinde muz meyvelerinde gerek yetiştiricilik sırasında ağaçlarda, gerekse derim sırasında, sarartma tesislerinde veya sarartma sonucunda depolama ve taşıma sırasında ciddi kayıplara neden olan önemli biyotik faktörlerin başında fungal hastalık etmenleri gelmektedir. Dünyanın önde gelen muz yetiştiricisi ülkelerde muz meyvelerinde derim sonrası sorun olan fungal hastalıkların belirlenmesine yönelik yapılan araştırmalarda farklı Fusarium spp., tarafından neden olunan Taç Çürüklüğü (=crown rot), Colletotrichum spp tarafından neden olunan Antraknoz, Lasiodiplodia theobromae tarafından neden olunan Lasiodiplodia Çürüklüğü, Thielaviopsis paradoxa tarafından neden olunan Thielaviopsis sap Çürüklüğü, Musicillium theobromae tarafından neden olunan Puro Uç Çürüklüğü (=cigar-end rot), Siyah Uç (black-end rot) ve Nigrospora sphaerica tarafınca neden olunan fışkırtma (=squirter) hastalıkları muz meyvelerinde en 
çok karşılaşılan hastalıklar olduğu bildirilmiştir (Ploetz ve ark., 1994; Ploetz, 1998; Alvindia ve ark, 2002; Kader, 2002; Snowdon, 2010; Lassois ve ark., 2010; UmanaRojas ve ark., 2011; Alvindia, 2013; Kamel ve ark., 2016; Jagana ve ark., 2017). Ülkemizde derim öncesi muz yetiştiriciliğinin yapıldığı alanlarda meyvelerde ve köklerde görülen fungal hastalık etmenlerin tespitine yönelik sınırlı sayıda survey çalışması mevcut olup (Turan, 1983), son yıllarda muz meyve ve köklerinden fungal hastalık etmenlerin bildirimleri yapılmaya başlanmıştır (Demiray ve ark., 2020; Uysal ve Kurt, 2020; Ozarslandan ve Akgul, 2020). Yapılan literatür araştırmasında, ülkemizde derim sonrası muz meyvelerinde görülen hastalıklar üzerine yapılmış bir çalışmaya rastlanılmamıştır.

Bu kapsamda yürütülmüş olan çalışmada, Mersin ilinin Bozyazı, Anamur, Erdemli gibi önemli muz üretiminin yapıldığı ilçelerdeki paketleme evlerinden hastalık belirtisi gösteren, göstermeyen veya şüpheli muz meyvelerinden örnekler alınmış, etilen uygulaması yapıldıktan sonra iklim odalarında tutulmuş ve depolama sonucu hastalık belirtisi gösteren meyve örneklerinden fungal hastalık etmenleri izole edilerek morfolojik olarak tanılanmıştır.

\section{MATERYAL ve YÖNTEM}

\section{Hastalık surveyi}

Çalışma materyali, Mersin illinde 2012 yılı Tarım il müdürlüğü verileri dikkate alınarak 2013 ve 2014 yıllarının değişik derim sezonlarında muz üretiminin ve paketlemesinin yoğun olarak yapıldığı Bozyazı, Anamur ve Erdemli ilçcelerindeki paketleme evlerinden temin edilmiştir (Çizelge 1). Meyve örnekleri yeni derim edilip paketleme evine getirilmiş, taraklar halinde kesilen meyvelerden oluşmuştur. Her paketleme evinden yaklaşık 6-7 parmaklık örnek alınarak polietilen torbalara konduktan sonra etilen gazı alımı için torbalar makasla delinmiş ve 4-5 gün sarartma tesisinde sarartmaya bırakılmıştır. Sarartma tesisinden alınan muzlar, 1 gün sonra torbalardan çıkarıldıktan sonra Alata Bahçe Kültürleri Araştırma Enstitüsü (ABKAE) iklimlendirme odasına $\left(14-15{ }^{\circ} \mathrm{C}\right)$ bırakılmıştır. İklimlendirme odasında tutulan muzlar 2 gün sonra incelenmiştir. Paketleme evlerinden alınan ve herhangi bir etilen uygulaması yapılmamış, hastalık belirtisi gösteren (özellikle puro uç çürüklüğü ve iç kararması belirtisi gösteren) veya şüpheli yeşil muz örneklerinden de izolasyon çalışmaları yapılmıştır.

\section{Hastalıklı örneklerden fungal hastalık etmenlerinin izolasyonu}

Meyvelerde hastalık belirtisine neden olan fungal hastalık etmenleri, farklı paketleme evlerinden toplandıktan sonra ABKAE'de bulunan iklimlendirilmiş odalarında bekletilen hastalık belirtisi gösteren muz meyvelerinden izole edilmiştir. İzolasyon sırasında hastalıklı bölge steril büstirü ile kesilerek dokunun hemen altındaki enfekteli bölgeden doku örnekleri alınmış ve alınan örnekler, içerisinde streptomycin sulfate (100 $\mathrm{mg} \mathrm{L}^{-1}$ ) bulunan Patates Dekstroz Agar (PDA) ortamına aktarılmıştır (Kurt ve ark., 2020). Bu petriler daha sonra $23 \pm 2{ }^{\circ} \mathrm{C}$ sıcaklıktaki inkübatörler içerisinde 34 gün gelişmeye bırakılarak fungal kolonilerin oluşması sağlanmıştır. Her petriye aynı enfeksiyon noktasından alınmış en az 2 farklı enfekteli doku konulmuş, bu dokulardan elde edilen fungal izolatların gelişmeleri her gün takip edilerek fungus izolatlarının birbirlerine karışmaması sağlanmıştır. Petrilerde gelişen farklı koloni gelişimi gösteren fungal izolatlar birbirlerine temas etmeden tekrar en uçtan alınan hifler ayrı ayrı yeni temiz petrilere aktarılarak saf fungus izolatları elde edilmiştir.

Fusarium türlerinin teşhislerinde; PDA ortamındaki koloni morfolojileri, pigmentasyon ve büyüme oranlarının yanı sıra, klamidospor üretimlerinin daha iyi gözlenmesi, üniform mikro ve makrokonidilerin oluşturması nedeni ile Karanfil Yaprak-Parçacık Agar (Carnation Leaf-Piece Agar, CLA) (Fisher ve ark., 1982) ortamı kullanılmıştır. Bu petriler daha sonra inkübatörler içerisinde $25^{\circ} \mathrm{C}^{\prime}$ de 7-10 gün inkübasyona bırakılmış ve gelişen çeşitli fungal etmenlerin teşhisi Nomarski DIC ekipmanlı ısık mikroskobu altında (Olympus BX 51) koloni gelişimi ve rengi, spor şekli ve rengi, klamidospor oluşumu, konidiyofor şekli gibi yapılarına göre teşhis edilmiştir. Fungal hastalık etmenlerinin teşhisinde; Fusarium spp için Booth (1977), Nelson ve ark. (1983) ve Leslie ve Summerell (2006); Alternaria spp. teşhisleri için Ellis (1993); Musicillium theobromae için Hawksworth ve Holliday, (1970); Deightoniella torulosa (Syd.) M.B. Ellis için Subramanian (1968); Thielaviopsis paradoxa (De Seynes) Höhn (syn. Chalara paradoxa) için PaulinMahady ve ark. (2002); Diğer konukçu dizilimi yüksek olan Penicillium spp., Rhizopus spp., Cladosporium spp. ve Aspergillus spp., gibi yaygın fungal türler için Sutton (1980), Barnett ve Hunter (2003), Klich (2002) tarafından bildirilen morfolojik özellikler göz önüne alınarak teşhisleri yapılmıştır. Teşhis edilen kültürlerden daha sonra patojenisite testinde kullanılmak üzere mümkün olduğunca tek sporlardan saflaştırılmış kültürler elde edilmiş ve saf kültürleri gelecekteki çalışmalarda kullanılıncaya kadar $+4{ }^{\circ} \mathrm{C}^{\prime}$ de eğik PDA besi ortamında muhafaza edilmiştir. 
Çizelge 1. Farklı survey tarihlerinde alınan hastalıklı muz meyve örneklerinden izole edilen fungal türleri, bulunuş oranları (\%) ${ }^{\mathrm{a}}$ Table 1. Fungal species isolated from diseased banana fruit samples taken at different survey dates, their incidence rates (\%)

\begin{tabular}{|c|c|c|c|c|c|c|c|c|c|c|c|c|c|c|c|}
\hline \multirow[b]{2}{*}{ İlçeler } & \multirow[b]{2}{*}{ Tarih } & \multirow[b]{2}{*}{$\begin{array}{c}\text { Toplam } \\
\text { örnek } \\
\text { sayısı }\end{array}$} & \multicolumn{5}{|c|}{ Taç Çürüklüğü } & \multicolumn{3}{|c|}{ Meyve Uç Çürüklüğü } & \multirow{2}{*}{$\begin{array}{l}\text { M.i.ç } \\
\text { F.v }\end{array}$} & \multicolumn{4}{|c|}{ Sekonder Hastalık Etmenleri } \\
\hline & & & $\begin{array}{c}\text { Fusarium } \\
\text { spp }\end{array}$ & F. $v$ & F. $o$ & $F \cdot p$ & $T . p$ & $\begin{array}{c}\text { Fusarium } \\
\text { spp }\end{array}$ & M. $t$ & D. $t$ & & A. $a$ & P.spp & A.n & C.c \\
\hline Bozyazı & 12.02 .2013 & 31 & 9 & 5 & 6 & 3 & 2 & 1 & 2 & 1 & 4 & 2 & 4 & 1 & 1 \\
\hline Anamur & 13.02.2013 & 29 & 11 & 7 & 4 & 5 & 1 & 2 & 1 & 1 & 3 & 7 & 1 & 3 & - \\
\hline Erdemli & 14.02.2013 & 17 & 4 & 4 & 5 & 2 & - & 4 & - & 1 & - & 2 & 5 & 2 & - \\
\hline Bozyazı & 9.12.2013 & 22 & 6 & 3 & 2 & 1 & 1 & 1 & - & - & 1 & 1 & - & 1 & - \\
\hline Anamur & 15.11.2013 & 33 & 5 & 4 & 2 & 4 & 1 & 3 & 1 & 1 & - & 3 & 4 & 2 & 1 \\
\hline Erdemli & 10.12.2013 & 9 & 4 & 2 & 1 & 1 & - & - & 1 & - & - & 1 & - & - & - \\
\hline Bozyazı & 6.05 .2014 & 23 & 8 & 4 & 2 & 2 & 1 & 2 & 1 & - & 1 & 3 & 2 & 1 & 1 \\
\hline Anamur & 7.05 .2014 & 22 & 2 & 1 & 2 & 4 & - & 2 & 1 & - & & 4 & 3 & - & - \\
\hline Erdemli & 8.05 .2014 & 11 & 3 & 2 & 1 & 1 & - & 3 & - & - & 1 & 3 & 2 & 1 & - \\
\hline \multirow{2}{*}{ TOPLAM } & Örnek & 197 & 52 & 32 & 25 & 23 & 6 & 18 & 7 & 4 & 10 & 26 & 21 & 11 & 3 \\
\hline & $\%$ & 100.00 & 21.8 & 13.4 & 10.5 & 9.7 & 2.5 & 7.6 & 2.9 & 1.7 & 4.2 & 10.9 & 8.8 & 4.6 & 1.3 \\
\hline
\end{tabular}

${ }^{a}$ Bulunuş oranı (\%)=Elde edilen izolat sayısının toplam izolat sayısına (238 adet) oranıdır. M.ì.Ç: meyve iç çürüklüğü; Fv: Fusarium verticillioides; Fo: Fusarium oxysporum; Fp: Fusarium proliferatum; Tp: Thielaviopsis paradoxa; Mt: Musicillium theobromae; Dt: .Deightoniella torulosa; Aa: Alternaria alternata; P. spp: Penicillium spp; An: Aspergillus niger; Cc: Cladosporium cladosporioides 


\section{Patojenisite çalışmaları}

Hastalık belirtisi gösteren meyvelerden elde edilen fungal etmenlerin patojenisite çalışmaları Alata Bahçe Bitkileri Araştırma Enstitüsünde bulunan seradan ve Erdemli'nin Limonlu beldesindeki bir üretici serasından elde edilen sağııklı meyveler üzerinde kontrollü yetiştirme odalarında yürütülmüştür. Farklı muz meyvesi örneklerinden izole edilen fungal izolatların patojenisite testlemelerinde bölgede yetiştirilen çeşitlerden" Azman" isimli muz çeşidi kullanılmıştır. Muz serasından alınan sağlıklı muz meyveleri öncelikle \% 0.25 lik sodyum hypokloritli suda yıkanmış, daha sonra üç ayrı kapta bulunan steril saf suda durulanmıştır. Yıkanarak yüzey sterilizasyonu yapılmış muz meyveleri ikili meyveler olacak şekilde ayrılmıştır (Şekil 8). Patojenisite testinde kullanılacak fungal izolatlar, PDA üzerinde 7 gün boyunca gelişmeye bırakılmıştır. Steril kabinde yürütülen patojenisite çalışmalarında, her bir çift muz meyvesinin taç çürüklükleri için, taç kısmında ve boyun kısmında; uç çürüklükleri için, çiçek ucunda steril mantar delici $(5 \mathrm{~mm}$ çapında) yardımı ile ayrı ayrı delikler açılmış, daha sonra fungus diskleri mantar deliciyle açılan yuvaya steril öze yardımıyla yerleştirilip nemli ortamın sağlanmıştır. Ayrıca yanı sıra fungus diskinin kurumaması için parafilm ile kapatılmıştır (Marin ve ark., 1996). Meyve iç çürüklüğüne neden olan fungal türlerin patojenisite testleri, sağlılı muz meyvelerin orta ekseninden ve uç kısmında steril şırınga ile meyve içine fungal etmenin spor süspansiyonu $\left(10^{4}\right.$ spor $\left.\mathrm{ml}^{-1}\right)$ enjekte edilerek yapılmıştır (Marin ve ark., 1996).

Her etmen için 5 çift muz meyvesi kullanılmıştır. İnokule edilmiş meyveler steril naylon poşetler içinde muz olgunlaştırma odasında $18{ }^{\circ} \mathrm{C}$ sıcaklık, \%90 bağıl nem ortamında 5 gün süre ile bekletilmiştir. Bu süre sonunda depoya $\left(15^{\circ} \mathrm{C}, \% 90 \pm 5 \mathrm{RH}\right)$ alınan muz meyveleri, 1 gün sonra poşetlerden çıkarılarak raf şartlarını sağlayan iklimlendirme odasına $\left(22 \pm 2^{\circ} \mathrm{C}, \% 80 \pm 5 \mathrm{RH}\right)$ alınmıştır. Bu şekilde iklimlendirme odasında 2 gün bekletilen meyveler incelenerek her bir meyve çiftinde inokulasyon noktalarındaki renk değişimi, nekroz ve çürüme gibi belirtiler esas alınarak hastalık oluşumu değerlendirilmiştir. İnokülasyondan yaklaşık 8 gün sonra patojenisite testlerinde kullanılan izolatlar, hastalık belirtileri gösteren meyvelerden tekrar izole edilerek orijinal izolatlar ile karşılaştırımıştır.

\section{BULGULAR ve TARTIŞMA}

\section{Derim sonrası muz meyvelerinde ortaya çıkan önemli hastalık belirtileri}

Surveyler Anamur, Bozyazı ve Erdemli gibi önemli muz yetiştiriciliği yapılan alanlarda, rastgele seçilmiş muz sarartma ve paketleme evlerinde 3 farklı derim döneminde (Şubat 2013, Kasım-Aralık 2013 ve Mayıs 2014) gerçekleştirilmiştir (Çizelge 1). Sarartma evlerinden alınan örnekler sarartmaya bırakılmış, sonra Alata Bahçe Kültürleri Araştırma Enstitüsündeki, iklimlendirme odasına alınmış ve iklimlendirme odasındaki muzlar 2 gün sonra incelenmiştir. Depolardan çıkartılan hastalık belirtileri gösteren meyve örneklerinden uygun besi yerleri üzerinde izolasyonlar yapılarak, hastalık etmenlerinin teşhisleri yapılmıştır. Survey sırasında alınan meyvelerden den izole edilen etmenlerin bulunuş oranları Çizelge $1^{\prime}$ de verilmiştir. Çizelge 1 de görüleceği gibi, 3 farklı derim zamanı surveyler sonucunda muz meyvelerinde ortaya çıkan hastalık belirtileri; taç çürüklüğü, meyve uç çürüklüğü, meyve iç çürüklüğü ve yüzeysel gelişen fırsatçı sekonder hastalık belirtileri olmak üzere 4 ana grup altında incelenmiştir. Surveyler süresince toplanan meyveler üzerinde hastalık belirtisi gösteren 197 örnekten toplam 238 adet fungal izolat elde edilmiştir.

\section{Meyve taç çürüklüğüne neden olan fungal hastalık etmenleri}

Muz meyvelerinde sıklıkla farklı türlere ait etmen(ler)in tek başına veya birlikte neden olduğu "taç çürüklüğü" hastalık kompleksi ile karşılaşılmış olup (Şekil 1a,b), yapılan izolasyonlar sonucunda farklı türlere ait toplam 138 fungal izolat (\%58) elde edilmiştir. Taç çürüklüğü hastalığı kompleksi içinde en çok bildirilen fungal hastalık etmenleri Fusarium spp.'ye dahil etmenlerdir (Alvindia ve ark., 2000; Hirata ve ark., 2001). Çalışmamızda da hastalıklı bitki örneklerinden izole edilen ve morfolojik fungal yapıları (Nelson ve ark., 1983; Leslie ve Summerell, 2006) baz alınarak yapılan tanılama çalışmaları sonucunda en fazla karşılaşılan izolatların Fusarium spp. ait olduğu görülmüştür (Şekil $1 \mathrm{c}, \mathrm{d}$ ve Çizelge 1). Bu izolatların büyük bir kısmı (\%21.8) tür düzeyinde tanımlanamazken, \%13.4'nün Fusarium verticillioides (Saccardo) Nirenberg, \%10.5'nin Fusarium oxysporum Schlechtendahl emend. Snyder \& Hansen ve \%9.7'nin Fusarium proliferatum (Matsushima) Nirenberg olduğu belirlenmiştir (Çizelge 1). Fusarium verticillioides, dünya çapında yaygın bir tür olup, Fusarium spp.'nin muzda Taç Çürüklüğü Hastalığına neden olduğu daha önce yapılan birçok çalışmada da bildirilmiştir (Li ve ark., 2012; Alvindia, 2013; Appiah-Sarpong ve ark., 2013; Molnar ve ark., 2015; Kamel ve ark., 2016; Abd-Murad ve ark., 2017; Kuyu ve Tola, 2018). Daha önce yapılan çalışmalarda muz meyvelerinde bildirilen Fusarium türlerini arasında $F$. semitectum, $F$. graminearum, $F$. subglutinans, $F$. camptoceras, $F$. solani, $F$. dimerum, $F$. acuminatum ve $F$. equiseti ve tanımlanamamıs diğer 
Fusarium spp olduğu bildirilmiştir (Turan, 1983; Jimenez ve ark., 1997; Krauss ve ark., 1993; Umana-Rojas ve Garcia, 2011).
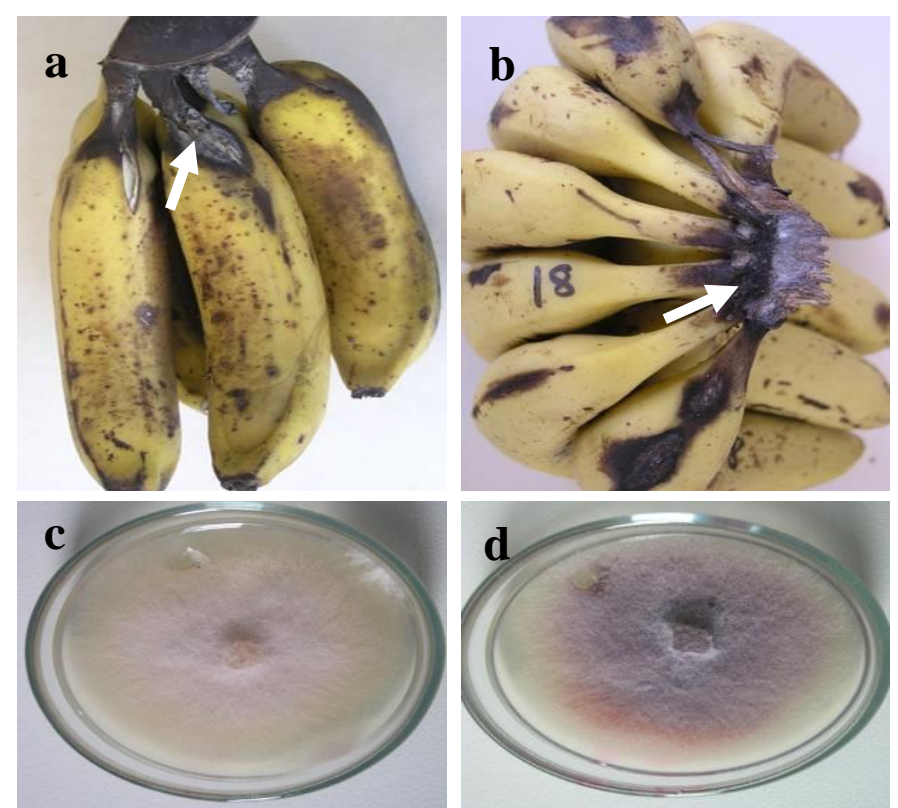

Şekil 1. (a ve b) Farklı Fusarium spp. tarafından muz meyvelerinde oluşturulan Taç Çürüklüğü Hastalığı belirtileri (ok). (c ve d) Enfekteli dokulardan PDA besi yeri üzerine izole edilen Fusarium verticillioides ve Fusarium proliferatum izolatlarının misel gelişimleri.

Figure 1. ( $a$ and b) Typical crown rot symptoms (arrows) caused by different Fusarium spp. on banana fruits. (c and d) Mycelial growth of Fusarium verticillioides and Fusarium proliferatum isolates obtained from infected tissues on PDA nutrient media.

Muz meyvelerinde taç çürüklüğüne neden olan Fusarium spp., dışında tespit edilen bir diğer fungal etmenin Thielaviopsis paradoxa (de Seyn.) Hohnel (syn. Chalara paradoxa (de Seyn.) Sacc. (Telemorf evresi: Ceratocystis paradoxa) olduğu belirlenmiştir (Şekil 2). Hastalık aynı zamanda Ceratocystis meyve çürüklüğü hastalığı olarak da bilinir. Muz meyvelerine genel olarak giriş yeri derimde kesilen sap ve hevenklerdir. Genel olarak taç çürüklüğü etmenlerinden olmasına rağmen, fungus nerede yara varsa oraya girip kolonize olabilir. Çürüklük markette olgun veya uzun süre olgun halde raflarda bekletilen meyvelerde görüldügünde, hastalık etmeni meyve etine saldırarak meyvenin yumuşamasına ve sulanmasına, kabuk dokusunun da kararmasına neden olur (Şekil 2a,b). Hastalık etmeninin varlığı daha önce Güney Afrika'da (Gorter, 1977), Hawaii (Raabe ve ark., 1981), Filipinler'de (Alvindia ve ark., 2002; Alvindia ve Natsuaki, 2007) ve Brezilya'da (de Melo ve ark., 2016) bildirilmiş olup, hastalık etmenin ülkemiz için varlığı ilk kez bu çalışma ile ortaya konulmuştur. Mersin ilinde yakın zamanda yapılan bir çalışma ile hastalığın varlığı bir kez daha teyit edilmiştir (Demiray ve ark., 2020).
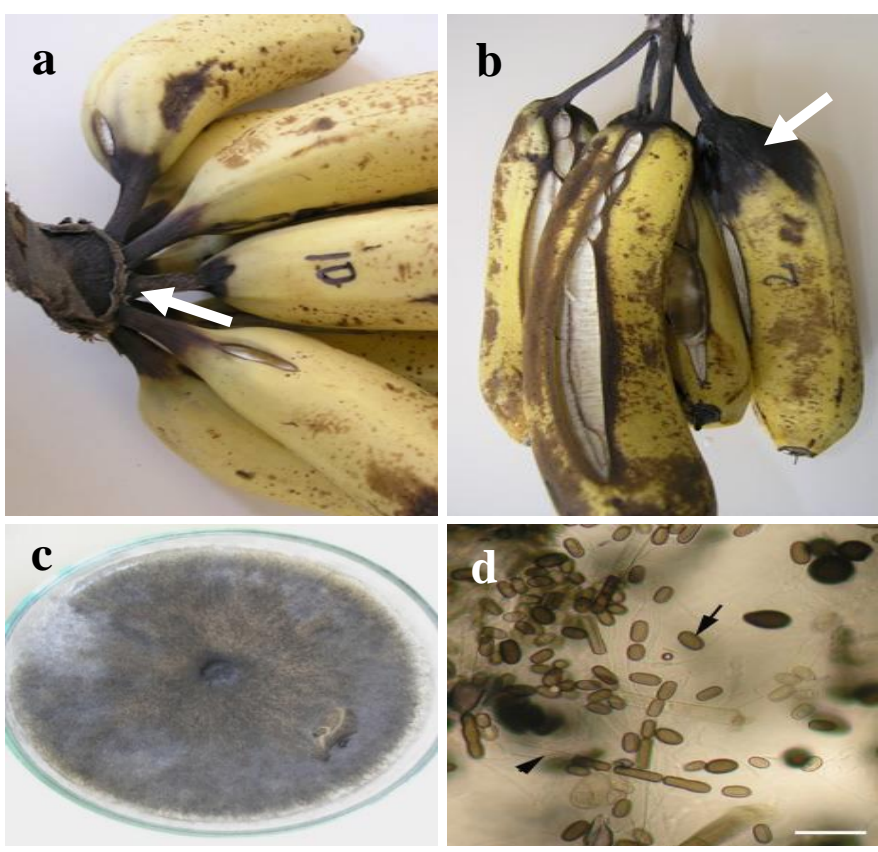

Şekil 2. (a ve b) Thielaviopsis paradoxa tarafından muz meyvelerinde oluşturulan sap çürüklüğü hastalık belirtileri (ok). (c ve d) Enfekteli dokulardan PDA besi yeri üzerine izole edilen Thielaviopsis paradoxa izolatı misel kültürü ve sporları (ok).

Figure 2. ( $a$ and b) Typical stalk rot symptoms (arrows) caused by Thielaviopsis paradoxa on banana fruits. (c and d) Mycelial growth and conidia (arrow) of Thielaviopsis paradoxa isolate obtained from infected tissues on PDA nutrient media.

\section{Meyve uç çürüklüğüne neden olan fungal hastalık etmenleri}

Yapılan gözlemlerde taç çürüklüğüne neden olan farklı Fusarium türleri, aynı zamanda meyvelerin çiçek burnundan başlayan ve meyve sapına doğru ilerleyen çürümelere de neden olmuştur. Hastalık etmen(ler)i tarafından saldırıya uğrayan bölgelerin kararıp sonuçta kuruduğu gözlenmiştir. Hastalıklı dokulardan genelde krem veya somon renkli miselyal gelişmesi gösteren farkıı Fusarium türleri izole edilmiştir (Şekil 3). Hastalık belirtileri Puro Uç Çürüklüğü hastalığından oldukça farklı olup, çürüklüğün olduğu bölgede yoğun havai misel gelişimi gözlenirken, yüzeyde görülen çürümelerin meyve etine veya orta kısmına ulaşmadığı gözlenmiştir (Şekil 3a,b). Çalışmamızda tespit edilen Musicillium theobromae (Turconi) Zare \& W. Gams tarafından neden olunan Puro Uç Çürüklüğü (=Cigar end rot) muzun önemli derim sonrası hastalıklarından birisi olup (Şekil 4), muz meyvesindeki zararı depolama sürecinin yanı sıra meyvelerin taşınması sırasında da ortaya 
çıkabilmektedir. Hastalık dünyanın muz üretiminin yapıldığı pek çok yerinde muz meyvesinin pazar değerini düşürmektedir. Hastalık etmenin ülkemizde varlığı, Turan (1983) tarafından yapılan çalışmada da meyve ağaçları üzerindeki muz meyvelerinde bildirilmiştir. Yapılan izolasyon çalışmalarımızda meyve uç çürüklüğüne neden olan etmenlerden birinin de Siyah Uç Hastalığı etmeni Deightoniella torulosa (Sydow) M.B. Ellis olduğu belirlenmiştir (Şekil 5). Hastalık belirtilerine genel olarak meyvede tek yönlü çürümeler şeklinde rastlanılmış olup, bazı durumlarda belirtilerin üzerinde Puro Uç Çürüklüğü Hastalığı belirtilerine de rastlanılmıştır (Şekil 5). Puro üç çürüklüğünde olduğu gibi meyve ucu kesildiğinde iç kısımda çürümenin olmadığı görülmüştür (Şekil 5b). Ülkemiz de dahil olmak üzere daha önce yapılan birçok çalışmada hastalık etmeninin muz bitkisinin yapraklarında lekelere neden olduğu bildirilmiştir (Turan, 1983; Photita ve ark., 2001; Koné ve ark, 2008; Leiva-Mora ve ark., 2013).
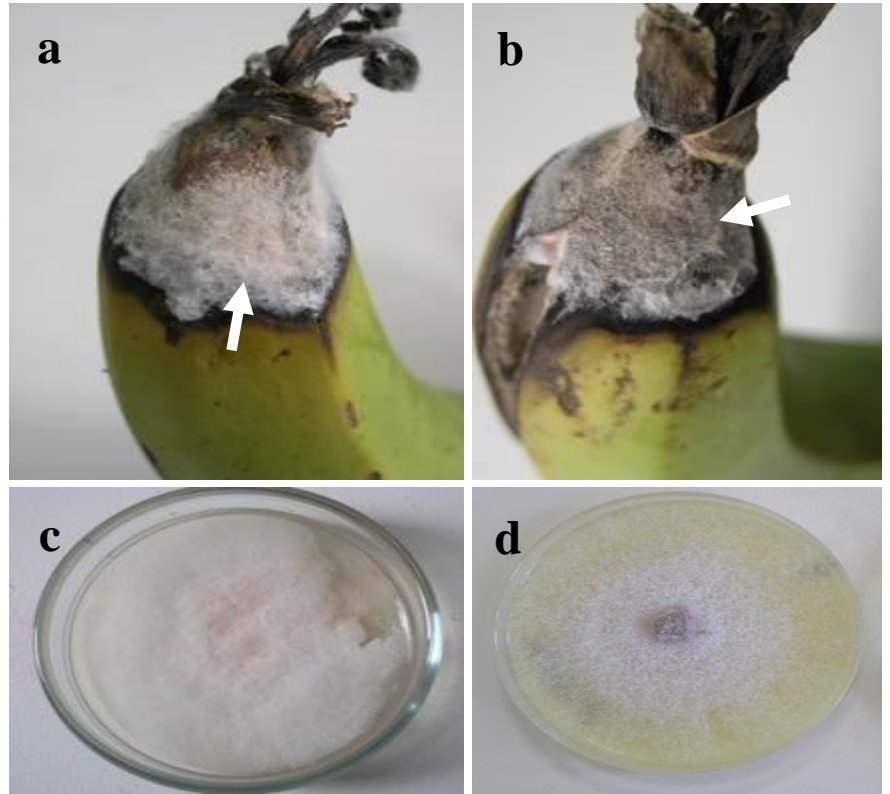

Şekil 3. (a ve b) Farklı Fusarium spp. tarafından muz meyvelerinde oluşturulan uç çürüklüğü hastalık belirtileri (ok). (c ve d) Enfekteli dokulardan PDA besi yeri üzerine izole edilen Fusarium spp. izolatının misel kültürü.

Figure 3. ( $a$ and b) Typical fruit end rot symptoms (arrows) caused by Fusarium spp. on banana fruits. (c and d) Mycelial growth of Fusarium spp. isolates obtained from infected tissues on PDA nutrient media.
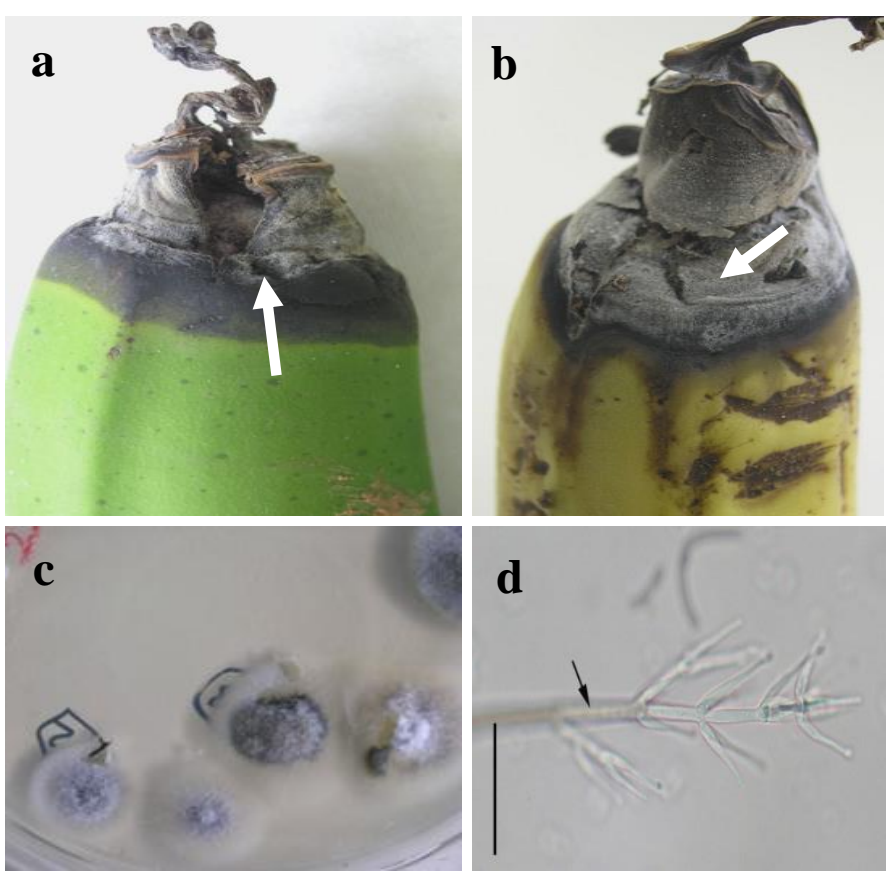

Şekil 4 (a ve b) Musicillium theobromae tarafından muz meyvelerinde oluşturulan Puro Uç Çürüklüğü hastalık belirtileri (ok). (c ve d) Enfekteli dokulardan PDA besi yeri üzerine izole edilen Musicillium theobromae izolatının misel kültürü ve tipik konidiofor yapısı (ok).

Figure 4. ( $a$ and b) Typical cigar end rot symptoms (arrow) caused by Musicillium theobromae on banana fruits. (c and d) Mycelial growth and typical conidiophore (arrow) of Musicillium theobromae isolate obtained from infected tissues on PDA nutrient media. 

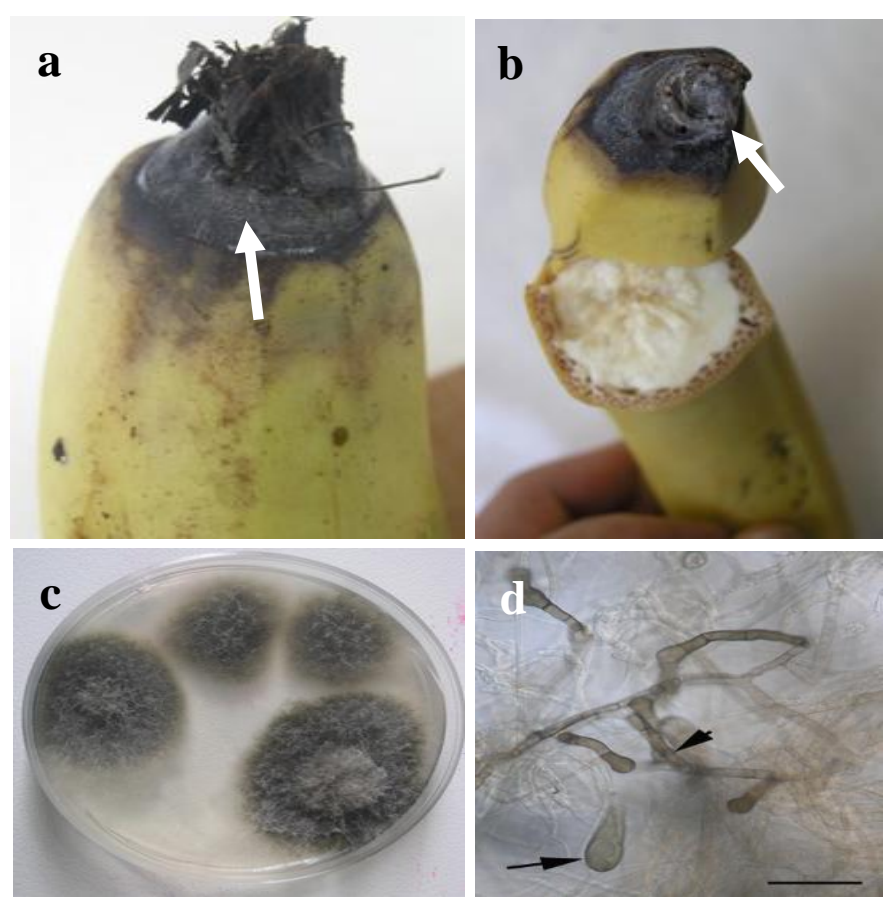

Şekil 5 (a ve b) Deightoniella torulosa tarafından muz meyvelerinde oluşturulan siyah leke ve uç çürüklüğü hastalık belirtileri (ok). (c ve d) Enfekteli dokulardan PDA besi yeri üzerine izole edilen Deightoniella torulosa izolatının misel kültürü ve tipik iri konidi ve konidiofor yapısı (ok).

Figure 5. (a and b) Typical black spot and end rot symptoms (arrow) caused by Deightoniella torulosa on banana fruits. (c and d) Mycelial growth and typical large conidia and conidiophore (arrow) of Deightoniella torulosa isolate obtained from infected tissues on PDA nutrient media.

\section{Meyve iç çürüklüğüne neden olan fungal hastalık etmenleri}

Enfekteli meyvelerin dışarıdan görünüşleri normal olup, sap ucunda veya çiçek ucunda herhangi bir çürüklük belirtisine rastlanılmazken, meyveler ortadan uzunlamasına kesildiğinde meyvenin merkezinde koyu kahverengi-siyah bir kararmanın uçtan sapa doğru uzandığı görülmüştür (Şekil 6a,b). Yapılan surveyler sırasında gerek üreticiler gerekse paketleme evlerindeki yetkililer, hastalıklı meyveleri bazı zamanlarda erken olgunlaşma (sararmasına) belirtilerine sebep olmasından dolayı sağlıkı meyvelerden ayrılabildiğini belirtilmişlerdir. Söz konusu meyvelerin iç çürüklüğünün görüldüğü kahverengi-siyah çürük bölgelerden yapılan izolasyonda hastalık etmeni Fusarium verticillioides izole edilmiştir (Şekil 6d). Snowdon (2010)'da bildirildiğine göre benzer belirtiler gösteren hastalığın İsrail'de "siyah kalp" (=Black heart) olarak rapor edildiği, hasta meyvelerde erken olgunlaşmanın görüldüğü bildirilmiştir.

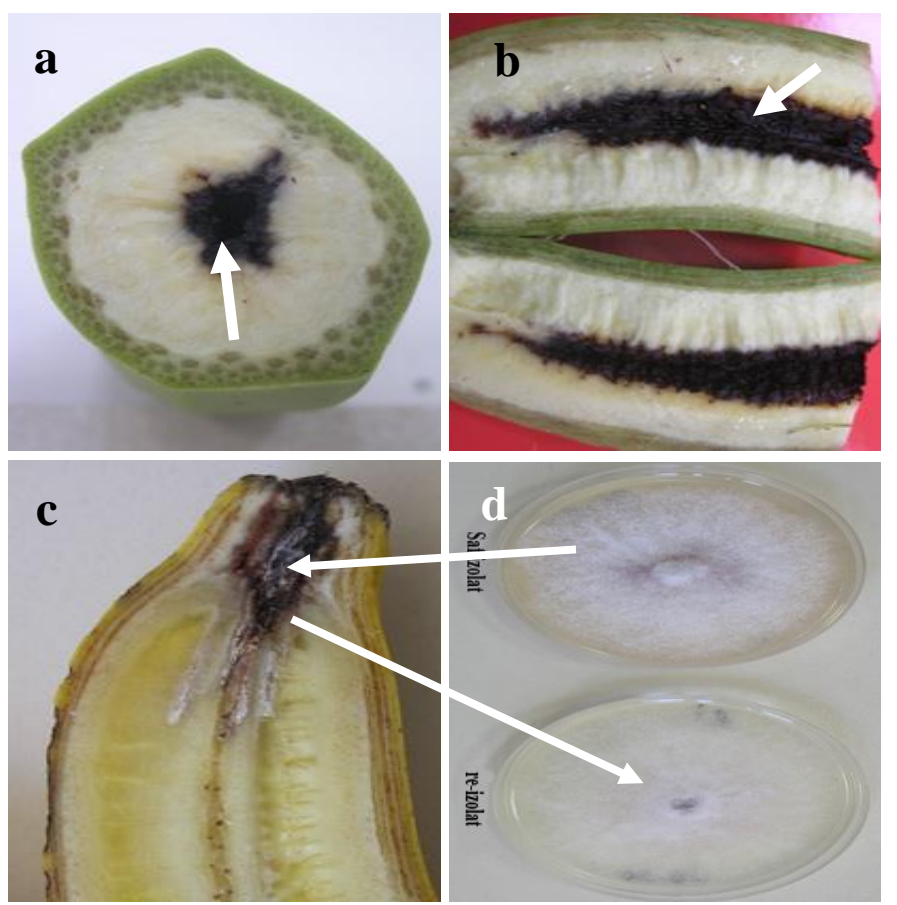

Şekil 6. (a ve b) Fusarium verticillioides tarafından muz meyvelerinde oluşturulan meyve iç çürüklüğü hastalık belirtileri (ok). (c ve d) Enfekteli dokulardan izole edilen izolatın patonisite testinde oluşturduğu belirtiler ve belirtilerden elde edilen re-izolatın PDA besi yeri üzerindeki misel kültürü (ok).

Figure 6. ( $a$ and b) Typical fruit internal rot symptoms (arrow) caused by Fusarium verticillioides on banana fruits (arrow). (c and d) Patojenicity test of Fusarium verticillioides isolate obtained from infected fruit tissues and re-isolation of fungal isolate from artificially inoculated fruit (arrow) on PDA nutrient media.

\section{Diğer sekonder fırsatçı (saprofit) fungal hastalık etmenleri}

Yapılan izolasyon çalışmaları sırasında, gerek taç çürüklüğü gösteren meyve örneklerinde gerekse uç çürüklüğü hastalık belirtileri gösteren meyvelerden, Fusarium spp, Deightoniella torulosa, Musicillium theobromae ve Thielaviopsis paradoxa gibi primer hastalık etmenlerinin yanı sıra 61 adet (\%25.6) fırsatçı hastalık etmenleri olarak bilinen az öneme sahip sekonder fungal etmenlerin sebep olduğu belirtilere de rastlanılmıştır (Şekil 7). Bu tür belirtiler gösteren meyvelerden yapılan izolasyonlar sonucunda Alternaria alternata en fazla rastlama sıklığı (\%10.9) ile elde edilen hastalık etmenlerinin başında gelirken, bu türü yeşil küf, çürüklük ve isli küf hastalıklarına neden olan Penicillium spp. (\%8.8), Aspergillus niger (\%4.6) ve Cladosporium cladosporioides (\%1.3) takip etmiştir (Çizelge 1 ve Şekil 7). Söz konusu fungal etmenlerin primer hastalıkların gözlendiği meyvelerde sıkça rastlanabileceği daha önce yapılan birçok çalışmada da bildirilmiştir (Marin ve ark., 
1996; Cao ve ark., 2002; Photita ve ark., 2003; Sarkar ve ark., 2009; Snowdon, 2010; Parkunan ve ark., 2013). Hastalık etmenlerin ülkemizde yetişen muz meyvelerindeki varlığı Turan (1983) tarafından yapılan önceki çalışmada da bildirilmiştir.
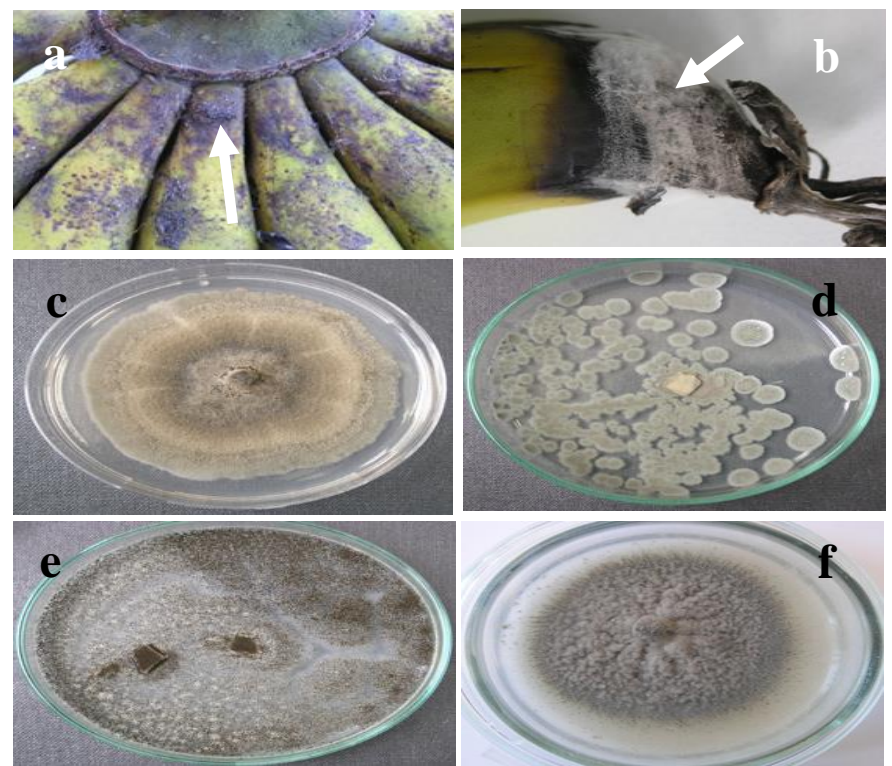

Şekil 7. (a ve b) Farklı sekonder fungal etmenlerinin muz meyvelerinde neden oldukları isli küf ve çürüklük hastalık belirtileri. (c-f) Hastalıklı dokulardan primer patojenlerin yanı sıra izole edilen sekonder fungal patojenler. (c) Alternaria alternata, (d) Penicillium sp., (e) Aspergillus niger ve (f) Cladosporium cladosporioides izolatının PDA besi yerindeki saf kültürleri

Figure 7. ( $a$ and b) Typical sooty mold and rot disease symptoms (arrow) caused by different secondary opportunistic fungal species on banana fruits. Typical mycelial growth of (c) Alternaria alternata, (d) Penicillium sp., (e) Aspergillus niger and ( $f$ ) Cladosporium cladosporioides isolates obtained from infected tissues on PDA nutrient media.

Muz meyvelerinde taç ve uç çürüklüğüne neden olan farklı Fusarium türleri, Deightoniella torulosa, Musicillium theobromae ve Thielaviopsis paradoxa etmenleri ile meyve iç çürüklüğüne neden olan Fusarium verticillioides'in patojenisiteleri sağlıklı muz meyveleri üzerinde yapılmış olup, inokulasyondan 8 gün sonra inokule edilmiş meyvelerin taç ile meyve saplarında ve uçlarında tipik hastalık belirtileri gözlenmiş, yapılan reizolasyonlarda meyveye hangi etmen verilmiş ise tekrar aynı koloni özelliğinde olan izolat geri elde edilmiştir (Şekil 8).

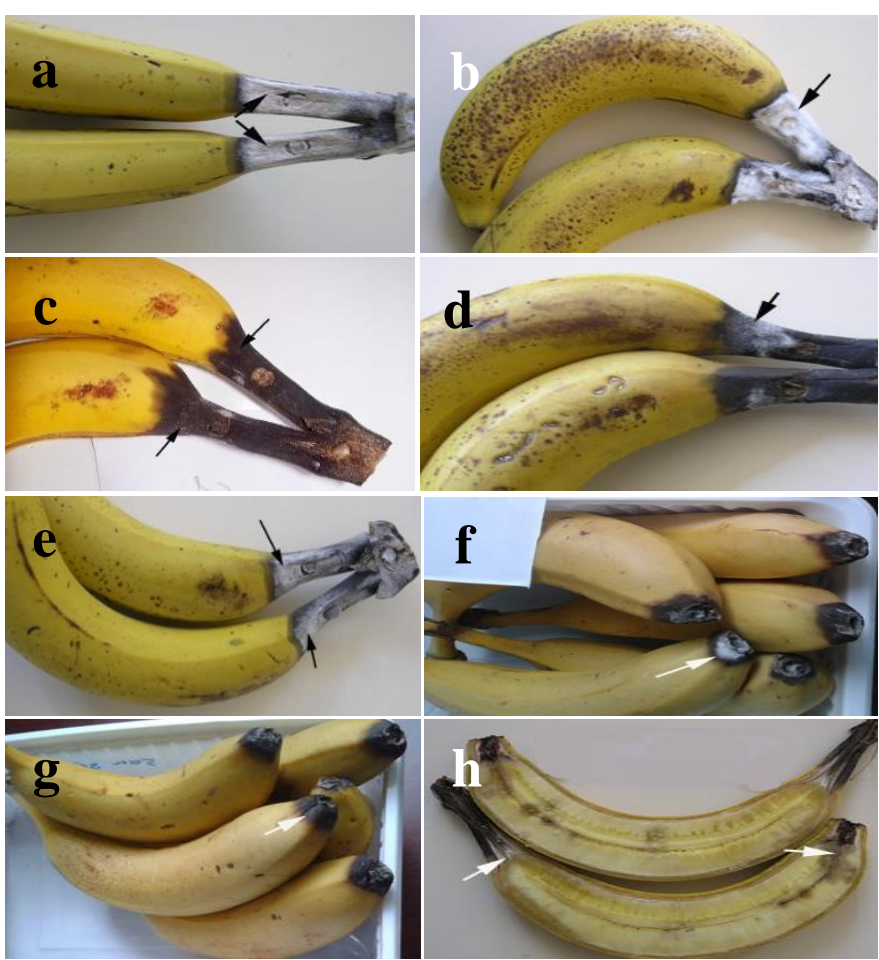

Şekil 8. Fusarium Taç çürüklüğü (a ve b), Thielaviopsis sap çürüklüğü (c ve d), Puro Uç Çürüklüğü (e ve f), siyah leke ve uç çürüklüğü (g) ve meyve iç çürüklüğü $(h)$ hastalık etmenlerinin patojenisite testi sonucu meyvelerde gözlenen tipik hastalık belirtileri (ok).

Figure 8. Pathogenicity tests of Fusarium crown rot (a and b), Thielaviopsis stalk rot (c and d), cigar end rot (e and f), black spot and end rot (g), fruit internal rot (h) disease agents on artificially inoculated banana fruits and typical disease symptoms observed (arrow).

Sonuç olarak, ülkemiz muz ekim alanlarında gözlenen hastalıklar hakkında yapılan genel survey çalışmasının (Turan, 1983) yanı sıra son yıllarda oldukça kısıtlı sayıda yapılmış hastalık bildirimi şeklinde çalışmalar bulunmaktadır (Demiray ve ark., 2020; Ozarslandan ve Akgul, 2020; Uysal ve Kurt, 2020). Ülkemizde muz meyvelerinde derim sonrasında önemli kayıplara neden olan fungal etmenlere ilişkin daha önce herhangi bir araştırma yapılmamıştır. Bu çalışma ile Mersin ili genelinde yetiştirilen muz meyvelerinde derim sonrasında ortaya çıkan, kalite ve kantite kayıplarına neden olan fungal hastalık etmenleri belirlenmiş olup, bu alandaki eksiklik kısmen de olsa giderilmiştir. Yapılan izolayon ve tanılama çalışmaları sonucu bölgede en önemli derim sonrası fungal hastalıkların başında yörede "takoz çürüklüğü" olarak da bilinen, Fusarium spp., $F$. verticillioides, $F$. oxysporum ve $F$. proliferatum gibi birden fazla fungal türlerce neden olunan Taç Çürüklüğü (crown rot) hastalık kompleksi olduğu belirlenmiştir. Fusarium cinsine ait türlerin teşhisleri, etmenlerin morfolojik 
özelliklerine göre yapılmış olup, son derece kompleks bir yapıya sahip olan bu türlerin morfolojik olarak büyük benzerlik göstermesi nedeni ile bu türlerin kesin tür teşhislerinin ilerde yapılacak olan moleküler çalışmalarla da desteklenebilir.

Muz meyvelerinde farklı Fusarium türleri dışında taçta çürüklük yapan, çalışmalarımızda da belirlenen ve "Thielaviopsis sap çürüklüğü" olarak adlandırılan hastalığın etmeni, Thielaviopsis paradoxa'dır. Bu patojenin muz meyvelerindeki varlığı ülkemizde ilk kez bu çalışma ile ortaya konulmuş olup, yakın zamanda benzer bildirim Demiray ve ark. (2020) tarafindan da yapılmıştır. Taç çürüklüğü belirtisi gösteren meyvelerden bu etmenler dışında Alternaria alternata, Penicillium spp., Cladosporium cladosporioides ve Aspergillus niger gibi sekonder çürükçül hastalık etmenleri de izole edilmiştir. Meyvelerde özellikle dıştan bakıldığında belli olmayan fakat meyve boyuna kesildiğinde merkezde çiçek ucu kısmından sapa kadar ilerleyen siyah renkte meyve iç çürüklüğü hastalık belirtileri gözlenmiştir. Bu tip belirtiler gösteren meyvelerin iç dokularından yapılan izolasyon çalışmaları sonucunda hastalığa neden olan etmenin Fusarium verticiliodies olduğu tespit edilmiştir. Yapmış olduğumuz gözlemlerimizde, hastalık etmenlerin muz meyvelerinin dış yüzeyde iç kısmında gözlenen çürüklüğe benzer herhangi bir belirtiye neden olmaması nedeni ile, bu hastalık etmenlerinin, derim öncesinde meyve gelişme aşamasındayken, çiçeklenme döneminde enfeksiyon yaptığı düşünülmektedir.

Derimden önce meyvelerde görülen fakat paketleme evlerinde hevenklerden ayıklanması nedeni ile derimden sonra pek ortaya çıkmayan bir diğer hastalık gurubu da uç çürüklükleridir. Meyve Uç Çürüklüğü hastalık belirtilerine neden olan etmenlerin, Fusarium spp., Fusarium verticillioides, Fusarium oxysporum ve Fusarium proliferatum'un yanısıra "Puro uç çürüklüğü"nün etmeni, Musicillium theobromae ve "Siyah uç çürüklüğü"nün etmeni Deightoniella torulosa olduğu belirlenmiştir. Paketleme evlerindeki yetkililer ile yapılan görüşmelerde, bu hastalık belirtisi gösteren meyvelerin daha çok nisbeten çiğlenmenin fazla olduğu alçak seralardan getirilen meyvelerde daha fazla görüldüğü belirtilmiştir. Muzun en çok yetiştiği tropikal bölgelerde önemli bir hastalık iken bizim bu çalışmamızda rastlamadığımız hastalık Colletotrichum musae tarafından neden olunan Antraknoz hastalığıdır. Ülkemizde yakın zamanda yapılan çalışmada Antraknoz hastalığının bir başka türü olan C. siamense meyvelerde tespit edilmiştir (Uysal ve Kurt, 2020).

Elde edilen sonuçlara göre derim sonrası muz meyvelerinde görülen hastalıkların bu derecede fazla görülmesinin en önemli nedenleri; derimden önce ve özellikle derimden sonra hastalık kontrolüne yönelik sanitasyon kurallarına yeterince uyulmaması, derim edilen muz hevenklerinde çiçek kalıntılarının yeterince temizlenmemesi ve muz hevenklerinin poşet torbalara alınmaması olarak sıralanabilir. Bu nedenlerin içinde en önemlisi derimden önce ve özellikle derimden sonra sanitasyona ve hijyene (özellikle hevenklerin yıkandığı tanklardaki yıkama sularının temizliğine) yeterince dikkat edilmemesidir. Bu bağlamda derim sonrası hastalık çıkışlarının engellenmesi için yapılması gereken işlerin başında yukarda bahsedilen olumsuzlukların giderilmesi gelmektedir.

\section{ÖZET}

Amaç: Bu çalışma, 2013-2014 yıllarında Mersin ilinin Bozyazı, Anamur, Erdemli gibi önemli muz üretiminin yapıldığı ilçelerindeki paketleme evlerinden alınan muz meyvelerinde hasat sonrası yaygın fungal hastalık etmenlerinin izolasyonu ve tanılaması amacıyla yapılmıştır.

Yöntem ve Bulgular: Mersin ilinin farklı ilçelerindeki depo ve paketleme evlerine 2013 ve 2014 muz yetiştirme sezonlarında yapılan surveylerde hastalıklı/şüpheli muz meyve örnekleri alınmıştır. Muz meyveleri üzerinde derim sonrası ortaya çıkan fungal hastalık etmenleri meyvelerden izole edilmiş ve morfolojik yapılarına göre tanılanmıştır. İzolasyonlar sonucu hastalık belirtisi gösteren 197 farklı hastalıklı meyveden toplam 238 fungal izolatı elde edilmiştir. Taç çürüklüğü hastalık belirtisi gösteren meyvelerden en fazla Fusarium spp (\%21.8) izole edilmiş olup, bu türleri sırası ile Fusarium verticillioides (\% 13.4), F. oxysporum (\% 10.5), F. proliferatum (\% 9.7) ve Thielaviopsis paradoxa (\% 2.5) izlemiştir. Meyve uç çürüklüğü belirtisi gösteren meyvelerden Fusarium spp. (\%7.6), Musicillium theobromae (\%2.9) ve Deightoniella torulosa (\%1.7) hastalık etmenleri izole edilmiştir. Meyvelerin merkez kısmında siyah iç çürüklük belirtilerine ise $F$. verticillioides'in (\%4.2) neden olduğu belirlenmiştir. Alternaria alternata (\%10.9), Penicillium spp. (\%8.8), Aspergillus niger (\%4.6) ve Cladosporium cladosporioides (\%1.3) gibi türlere ait izolat ise farklı çürüme belirtileri gösteren muz meyve üzerinde sekonder (fırsatçı) hastalık etmenleri olarak belirlenmiştir.

Genel Yorum: Ülkemizde muz meyvelerinde derim sonrasında önemli kayıplara neden olan fungal etmen(ler)e ilişkin daha önce herhangi bir araştırma yapılmamıştır. Bu çalışma ile Mersin ili genelinde yetiştirilen muz meyvelerinde derim sonrasında ortaya çıkan, kalite ve ürün kayıplarına neden olan fungal hastalık etmenleri belirlenmiş olup, bu alandaki eksiklik 
kısmen de olsa giderilmiştir.

Çalışmanın Önemi ve Etkisi: Bu çalışmada elde edilen sonuçlar, gelecekte muz meyvelerinde öncelikle çalışıması gereken derim sonrası hastalıklar ve mücadelesi üzerine yapılacak çalışmalara ışık tutacak niteliktedir.

Anahtar Kelimeler: Muz, derim sonrası, fungal hastalık etmenleri, meyve çürüklüğü.

\section{TEŞEKKÜR}

Bu çalışma Hatay Mustafa Kemal Üniversitesi Bilimsel Araştırma Projeleri Komisyonu Başkanlığı tarafından finansal olarak desteklenmiştir (Proje Numarası: MKU BAP-321). Bu çalışmanın özeti 2-6 September 2016 tarihinde Konya ilinde düzenlenmiş olan 6. Uluslararası Katılımlı Türkiye Bitki Koruma Kongresinde sunulmuştur.

\section{ÇIKAR ÇATIŞMA BEYANI}

Yazar(lar) çalışma konusunda çıkar çatışmasının olmadığını beyan eder.

\section{ARAŞTIRMACILARIN KATKI ORANI BEYANI}

Yazarlar çalışmaya eşit oranda katkı sağlamış olduklarını beyan eder.

\section{KAYNAKLAR}

Abd-Murad NB, Nor NMIM, Shohaimi S, Zainudin NAIM (2017) Genetic diversity and pathogenicity of Fusarium species associated with fruit rot disease in banana across Peninsular Malaysia. J. Appl. Microbiol. 123: 1533-1546.

Alvindia DG (2013) An integrated approach with hot water treatment and salt in the control of crown rot disease and preservation of quality in banana. Int. J. Pest Manag. 59: 271-278.

Alvindia DG, Kobayashi T, Yaguchi Y, Natsuaki KT (2000) Symptoms and the associated fungi of postharvest diseases on non-chemical bananas imported from the Philippines. Jpn. J. Trop. Agric. 44: 87-93.

Alvindia DG, Kobayashi T, Yaguchi Y, Natsuaki KT (2002) Pathogenicity of fungi isolated from non-chemical bananas. Jpn. J. Trop. Agric. 44: 215-223.

Alvindia DG, Natsuaki KT (2007) Control of crown rotcausing fungal pathogens of banana by inorganic salts and a surfactant. Crop Protect. 26: 1667-1673.

Anonim (2010) Muz yetiştiriciliği. http://www.bahcebitkileri.org

Anonim (2020) TUiK Bitkisel Üretim İstatistikleri. https://biruni.tuik.gov.tr/medas/?kn=92\&locale=tr (Erișim Tarihi: 25 Nisan 2021).
Anonymous (2018) FAOSTAT Statistic Database. (Retrieved December 25, 2018, from http://www.fao.org/faostat/en/\#data/QC/visualize).

Appiah-Sarpong $M$, Kumah $P$, Olympio NS, Moses $E$ (2013). In vitro management of crown rot disease of banana (Musa spp. AAA) 'medium cavendish' using extracts from Ocimum gratissimum, Alstonia boonei and Garcinia kola. Acta Hortic. 1007: 739-746.

Arias P, Dankers C, Liu P, Pilkauskas P (2003) The World Banana Economy. Food and Agriculture Organization of the United Nations. Rome.

Barnett HL, Hunter BB (2003) Illustrated genera of imperfect fungi. 4 ed. Burgess Publishing Company Minneapolis 15, Minn.

Basel RM, Racicot K, Senecal AG (2002) Long shelf life banana storage using MAP storage coupled with postharvest MCP treatment. Annl. Meeting Food Expo-Anaheim, Cal., USA, June 15-19, 2002.

Booth C (1977) Fusarium. Laboratory guide to the identification of the major species. Commonwealth Mycology Institute, Kew. 58 pp.

Cao LX, You JL, Zhou SN (2002) Endophytic fungi from Musa acuminata leaves androots in South China. World J. Microbiol. Biotechnol. 18: 169-171.

de Melo MP, Matos KD, Beserra JEA, Moreira SI, Silva FF, Neto FD, Alves E, Pereira OL (2016) Thielaviopsis musarum causes postharvest crown and fruit rot of banana in Northeastern Brazil. Trop. Plant Pathol. 41: 258-263.

Demiray ST, Akcali E, Uysal A, Kurt S (2020) First report of Thielaviopsis paradoxa causing main stalk rot on banana in Turkey. Plant Dis. 104:2733-2734.

Ellis MB (1993) Dematiaceous Hypomycetes. CAB, Kew, $608 \mathrm{pp}, \mathrm{UK}$.

Fisher NL, Burgess LW, Toussoun TA, Nelson PE (1982) Carnation leaves as a substrate and for preserving cultures of Fusarium species. Phytopathology 72: 151-153.

Gangwar D, Katıyar PN, Singh JP, Singh PC (2008) Effect of post-harvest chemical treatments on shelf life an physic chemical quality of banana cv. Harichal. Asian J. Hort. 3: 386-388.

Gorter GMJA (1977) Index of plant pathogens and the diseases they cause in cultivated plants in South Africa. PPRI Sci. Bullet. 392: 177 pp.

Hawksworth DL, Holliday P (1970) Verticillium theobromae. CMI Descriptions of Pathogenic Fungi and Bacteria 259:2 pp

Hirata T, Kimishima E, Aoki T, Nirenberg HI, O'Donnell K (2001) Morphological and molecular characterization of Fusarium verticillioides from rotten banana imported into Japan. Mycoscience, 42: 155-166. 
Jagana D, Hegde YR, Rajasekhar L (2017) Post harvest diseases of banana (Musa paradisiaca L.)- A survey and pathological investigations. Int. J. Pure App. Biosci. 5 (5): 706-714.

Jimenez M, Logrieco A, Bottalico A (1993) Occurrence and pathogenicity of Fusarium species in banana fruits. J. Phytopathol. 137: 214-220.

Kader AA (2002) Postharvest technology of horticultural crops. Univ of California Agriculture \& Natural Resources, 535 s. California.

Kamel MAM, Cortesi P, Saracchi M (2016) Etiological agents of crown rot of organic bananas in Dominican Republic. Postharvest Biol. Technol. 120: 112-120.

Klich MA (2002) Identification of common Aspergillus species. Centraalbureau voor Schimmelcultures: Utrecht, The Netherlands.

Koné D, Ji P, Fonsah GE, Csinos AS (2008) First report of black leaf spot of banana caused by Deightoniella torulosa in Georgia. Plant Dis. 92: 1470.

Krauss U, Bidwell R, Ince J (1998) Isolation and preliminary evaluation of mycoparasites as biocontrol agents of crown rot of banana. Biol.Control 13: 111-119.

Kurt Ş, Soylu S, Uysal A, Soylu EM, Kara M (2020) Ceviz gövde kanseri hastalığı etmeni Botryosphaeria dothidea'nın tanılanması ve bazı fungisitlerin hastalık etmenine karşı in vitro antifungal etkinliklerinin belirlenmesi. MKU. Tar. Bil. Derg. 25(1) : 46-56.

Kuyu CG, Tola YB (2018) Assessment of banana fruit handling practices and associated fungal pathogens in Jimma town market, southwest Ethiopia. Food Sci. Nutr. 6: 609-616.

Lassois L, Jijakli MH, Chillet M, de Bellaire LD (2010) Crown rot of bananas preharvest factors involved in postharvest disease development and integrated control methods. Plant Dis. 94: 648-658.

Leiva-Mora M, Alvarado-Capó Y, Acosta-Suárez M, CruzMartín M, Roque B, Carrera K (2013) Deightoniella torulosa (Syd.) M.B. Ellis, causing leaf spot in acclimatized Grande naine (Musa, AAA) plants. Rev. Protección Veg. 28: 145-148.

Leslie JF, Summerell BA (2006) The Fusarium Laboratory Manual, Blackwell Publishing: Hoboken, lowa, USA, $388 \mathrm{pp}$.

Li J, Jiang GX,Yang B,Dong XH,Feng LY,Lin S, Chen F, Ashraf M, Jiang YM (2012) A luminescent bacterium assay of fusaric acid produced by Fusarium proliferatum from banana. Anal. Bioanal. Chem. 402: 1347-1354.
Marin DH, Sutton TB, Blankenship SM, Swallow WH (1996) Pathogenicity of fungi associated with crown rot of bananas in Latin America on Grande Naine and disease-resistant hybrid bananas. Plant Dis. 80: 525528.

Molnar O, Bartok T, Szecsi A (2015) Occurrence of Fusarium verticillioides and Fusarium musae on banana fruits marketed in Hungary. Acta. Microbiol. Immunol. Hung. 62: 109-119.

Nelson PE, Toussoun TA, Marasas WFO (1983) Fusarium Species: An Illustrated Manual for Identification. Pennsylvania State University, University Park. 193 pp, USA.

Ozarslandan M, Akgul DS (2020) First report of Fusarium oxysporum f. sp. cubense Race 4 causing Fusarium wilt disease of banana in Turkey. Plant Dis. 104: 974974.

Parkunan V, Li S, Fonsah EG, Ji P (2013) First report of Alternaria leaf spot of banana caused by Alternaria alternata in the United States. Plant Dis. 97: 1116.

Paulin-Mahady AE, Harrington TC, McNew D (2002) Phylogenetic and taxonomic evaluation of Chalara, Chalaropsis, and Thielaviopsis anamorphs associated with Ceratocystis. Mycologia 94: 62-72.

Photita W, Lumyong P, McKenzie EHC, Hyde KD, Lumyong S(2003) Saprobic fungi on dead wild banana. Mycotaxon 85: 345-346.

Photita W, Lumyong S, Lumyong $\mathrm{P}$, Ho WH, McKenzie EHC, Hyde KD (2001) Fungi on Musa acuminata in Hong Kong. Fungal Divers. 6: 99-106.

Pınar H, Türkay C, Denli N, Ünlü M, Bircan M (2011) Türkiye'de muz üretim potansiyeli. GAP VI. Tarım Kongresi, 09-12/05/2011. Şanlıurfa.

Ploetz RC, Zentmyer GA, Nishijima WT, Rohrbach KG, Ohr HD (1994) Compendium of tropical fruit diseases. APS Press. The American Phytopathology Society

Ploetz RC (1998) Banana diseases in the subtropics: a review of their importance, distribution and management. Acta Hortic. 490: 263-276.

Raabe RD, Conners IL, Martinez AP (1981) Checklist of plant diseases in Hawaii. Hawaii Institute of Tropical Agriculture and Human Resources, College of Tropical Agriculture and Human Resources, University of Hawaii, Information Text Series 22: 1- 313.

Sarkar S, Girisham S, Reddy SM (2009) Incidence of postharvest fungal diseases of banana fruit in Warangal market. Indian Phytopathol. 62:103-105.

Snowdon AL (2010) A colour atlas of postharvest diseases and disorders of fruits and vegetables-. Volume 1: General introduction and fruits. Wolfe Scientific, Spain, 302 pp. 
Subramanian CV (1968) Deightoniella torulosa. C.M.I. Descr. Pathog. Fungi Bact. 165: 1-2.

Sutton BC (1980) The coelomycetes. CAB Publishing, Kew, England, CMI. 696 p.

Turan K, (1983) Akdeniz Bölgesi muz plantasyonlarında fungal hastalıkların belirtileri ve türlerinin tanımı üzerinde araştırmalar. T.C. Tarım ve Köyşsleri Bakanlığı Adana Zirai Mücadele ve Araştırma Enstitüsü Müdürlüğü, Araştırma Eserler Serisi No:52, Ankara, 47 sayfa.
Umana-Rojas G, Garcia J (2011) Frequency of organisms associated with crown rot of bananas in integrated and organic production systems. Acta Hortic. 906: 211-217.

Uysal A, Kurt S (2020) First report of Colletotrichum siamense causing anthracnose on banana fruits in Turkey. Plant Dis. 104: 967-96. 